\title{
scripted
}

Volume 15, Issue 2, October 2018

\section{Territoriality in Intellectual Property Law: Examining the Tension between Securing Societal Goals and Treating Intellectual Property as an Investment Asset}

\author{
Emmanuel Kolawole Oke*
}

\section{(c) (1) $\odot$}

(C) 2018 Emmanuel Kolawole Oke

Licensed under a Creative Commons Attribution-NonCommercial-

NoDerivatives 4.0 International (CC BY-NC-ND 4.0) license

DOI: $10.2966 /$ scrip.150218.313

\begin{abstract}
The principle of territoriality is one of the foundational principles of International Intellectual Property Law. This principle allows countries to design their intellectual property laws in a manner that facilitates the achievement of specific societal goals. However, while it is true that this principle has managed to survive the incorporation of intellectual property into the international trade law system (via the WTO's TRIPS Agreement), some scholars have expressed concern that the incorporation of intellectual property into the international investment law system via investment agreements (such as bilateral investment treaties) constitutes a potential threat to the principle of territoriality in the international intellectual property system. This paper will investigate the tension between the principle of territoriality and the global harmonisation of intellectual property standards in the context of the current iteration of intellectual property as an asset in investment agreements. Specifically, it will critically examine how this tension was resolved in two recent investment arbitration disputes. The first is the dispute between Philip Morris and
\end{abstract}


Uruguay which concerned the latter's implementation of certain measures to curb the consumption of tobacco products in its country but which Philip Morris construed as an expropriation of its trademarks. The second is the dispute between Eli Lilly and Canada which concerned the interpretation of the utility requirement under Canadian patent law. These cases will be used to assess whether there is still scope for the preservation of the principle of territoriality within the investor-state dispute settlement system.

\section{Keywords}

International intellectual property law; international investment law; investor-state dispute settlement system; Uruguay; Canada; Philip Morris

* Lecturer in International Intellectual Property Law, Edinburgh Law School, University of Edinburgh, Edinburgh, United Kingdom, emmanuel.oke@ed.ac.uk 


\section{Introduction}

The principle of territoriality is one of the foundational principles of International Intellectual Property Law (IIPL). ${ }^{1}$ According to the principle of territoriality, intellectual property rights are limited to the territory of the country where they have been granted. ${ }^{2}$ The principle of territoriality permits states to tailor their national intellectual property laws to suit their level of technological and economic development. In other words, pursuant to the principle of territoriality, countries can design their intellectual property laws in a manner that facilitates the achievement of specific societal goals such as encouraging the development of home-grown industries or protecting public health. Despite increased globalisation and the growth of international agreements dealing with intellectual property rights, the principle of territoriality is still regarded as a basic tenet of IIPL.

The principle of territoriality in International Law has its roots in the emergence of nation-states and this emergence is typically attributed to the Peace of Westphalia of $1648^{3}$ although, as a concept in political theory, territory predates the 17 th century. ${ }^{4}$ The history of intellectual property rights, at least from a Euro-centric perspective, is inextricably linked with territoriality. ${ }^{5}$ As

1 See, Hanns Ullrich, “TRIPS: Adequate Protection, Inadequate Trade, Adequate Competition Policy" (1995) 4(1) Pacific Rim Law \& Policy Journal 153-210, p. 157 (noting that, “The international protection of technological property has been governed by three interdependent principles: 1) territoriality of protection; 2 ) national treatment of foreign owners of national intellectual property; and 3) international minimum protection.").

2 Lydia Lundstedt, Territoriality in Intellectual Property Law (Stockholm University, 2016), p. 91.

3 See, Leo Gross, "The Peace of Westphalia, 1648-1948" (1948) 42(1) American Journal of International Law 20-41, pp. 28-29. See also, Derek Croxton, "The Peace of Westphalia and the Origins of Sovereignty" (1999) 21(3) The International History Review 569-591; Lundstedt, supra n. 2, p. 28.

4 See, Jean Gottmann, "The Evolution of the Concept of Territory" (1975) 14(3) Social Science Information 29-47, pp. 29-30.

5 Lundstedt, supra n. 2, p. 122. 
Lundstedt notes, "the origin of IP rights, in particular patent and copyright, is usually traced back to the privileges granted by the European sovereigns from the time of the 15th century" and these "privileges were expressly limited to a specific territory under the control of the sovereign." ${ }^{\prime} \mathrm{It}$ is noteworthy that these privileges have historically been regarded as instruments of "public policy regulation to control and monitor particular industries." 7 In other words, these privileges were utilised by sovereigns to achieve specific societal goals within their territories. ${ }^{8}$

The international intellectual property system evolved in response to the principle of territoriality. As a result of increased cross-border trade, states began to enter into bilateral treaties to protect intellectual property rights of their citizens abroad ${ }^{9}$ and this process eventually led to the emergence of two multilateral treaties on intellectual property towards the end of the nineteenth century i.e. the Paris Convention for the Protection of Industrial Property (Paris Convention) of 1883, and the Berne Convention for the Protection of Literary and Artistic Works (Berne Convention) of $1886 .{ }^{10}$

While both the Paris and Berne Conventions are the first multilateral treaties on intellectual property rights, they still preserved the principle of territoriality and member states were largely permitted to design their national intellectual property laws in a manner that suits their needs and interests as long

\footnotetext{
Ibid., pp. 73-74.

Ibid., p. 73.

8 See, Chris Dent, "'Generally Inconvenient': The 1624 Statute of Monopolies as Political Compromise" (2009) 33(2) Melbourne University Law Review 415-453, p. 418.

9 Lundstedt, supra n. 2, p. 85.

10 Peter Drahos, "Intellectual Property and Human Rights" (1999) 3 Intellectual Property Quarterly 349-371, pp. 351-358 (tracing the history of the international intellectual property system).
} 
as the principle of national treatment is respected. ${ }^{11}$ Subsequently, towards the end of the twentieth century, intellectual property was incorporated into the international trade law system via the WTO Agreement on Trade-Related Aspects of Intellectual Property Rights (TRIPS Agreement) of 1994. Unlike the Paris and Berne Conventions, the TRIPS Agreement significantly encroaches upon the principle of territoriality as it contains certain minimum standards that member states are required to implement at the national level. Nevertheless, the TRIPS Agreement still accords some level of recognition to the principle of territoriality ${ }^{12}$ as it contains a number of flexibilities that allow countries to calibrate their national intellectual property laws to their level of technological and economic development. ${ }^{13}$

Thus, in spite of globalisation and the ease with which products protected by intellectual property rights can cross national borders as a result of technological advancements, the principle of territoriality is still an integral component of IIPL. This implies that there is a continuing tension between the desire and drive (typically from multinational corporate actors trying to secure their intellectual property rights in several countries) for uniform/harmonised intellectual property standards on the one hand, and the desire and demand of several states to tailor their national intellectual property laws to suit their technological and economic needs on the other hand. Commenting on the continuing relevance of the principle of territoriality in the context of intellectual property law, Kur and Dreier note that,

11 The principle of national treatment is enshrined in the Paris Convention art. 3, the Berne Convention art. 5, and the TRIPS Agreement art. 3.

12 See for instance the TRIPS Agreement art. 1(1). See also, Rochelle Dreyfuss and Susy Frankel, "From Incentive to Commodity to Asset: How International Law is Reconceptualizing Intellectual Property" (2014) 36(4) Michigan Journal of International Law 557-602, p. 565.

13 See the objectives and principles contained in the TRIPS Agreement arts. 7 and 8. See also the WTO's Doha Declaration on the TRIPS Agreement and Public Health, 2001. 
The reason for the still prevailing emphasis of the principle of territoriality may be explained by political reasons...Today, when most states are under an obligation to recognize at least some sort of IP protection, the issue has become one of fine-tuning a state's national legislation to that state's particular economic, innovative, creative and consumptive needs. In other words, the principle of territoriality enables nation states to exercise an albeit limited - freedom to adjust their IP policies and following their national IP laws to their particular national needs. These needs greatly differ between industrialised, newly industrialised or threshold countries and developing countries, between net exporters and net importers of IP-related goods and services. ${ }^{14}$

However, while it is true that the principle of territoriality has managed to survive the incorporation of intellectual property into the international trade law system (albeit in an attenuated form), some scholars have expressed concern that the incorporation of intellectual property into the international investment law system via investment agreements (such as bilateral investment treaties and investment chapters of free trade agreements) constitutes a potential threat to the principle of territoriality in the international intellectual property system. ${ }^{15}$ The

14 Annette Kur and Thomas Dreier, European Intellectual Property Law: Text, Cases and Materials (Edward Elgar, 2013), p. 13. (Footnote omitted.) See also, Justine Pila and Paul Torremans, European Intellectual Property Law (Oxford University Press, 2016), p. 30.

15 Peter Drahos, "BITS and BIPS: Bilateralism in Intellectual Property" (2001) 4(6) Journal of World Intellectual Property 791-808; Cynthia Ho, "Sovereignty under Siege: Corporate Challenges to Domestic Intellectual Property Decisions" (2015) 30(1) Berkeley Technology Law Journal 213-304; Dreyfuss and Frankel, "From Incentive to Commodity to Asset", supra n. 12; Susy Frankel, "Interpreting the Overlap of International Investment and Intellectual Property Law" (2016) 19(1) Journal of International Economic Law 121-143. It should be stressed that bilateral investment treaties are not a recent phenomenon. The first bilateral investment treaty was signed between West Germany and Pakistan in 1959. (See, Treaty for the Promotion and Protection of Investments (Germany-Pakistan), (25 November 1959) 457 UNTS 6575). What is new in this regard is the use of the ISDS system by investors to challenge intellectual property laws before investment tribunals. See, Peter Yu, "The 
incorporation of intellectual property rights into investment agreements as investment assets has been aptly termed the "assetization" of intellectual property by Dreyfuss and Frankel. ${ }^{16}$

The incorporation of intellectual property into the international investment law system and the assetization of intellectual property can affect the principle of territoriality in at least two ways. Firstly, free trade agreements (especially where it is an agreement between a developed country and a developing country) typically include provisions requiring the parties to implement standards that are above and beyond the minimum requirements of the TRIPS Agreements or which eliminates a flexibility available to a WTO member under the TRIPS Agreement (typically referred to as TRIPS-plus provisions). ${ }^{17}$ Where an agreement expressly contains such TRIPS-plus provisions, it can curtail the ability of a party to design its national intellectual property laws in a manner that allows it to achieve specific societal goals. ${ }^{18}$ It is however possible to incorporate specific provisions into a bilateral investment treaty or a free trade agreement that recognises a country's policy space and preserves its regulatory powers with regard to intellectual property. ${ }^{19}$

Investment-Related Aspects of Intellectual Property Rights" (2017) 66(3) American University Law Review 829-910, pp. 837-844.

16 Dreyfuss and Frankel, "From Incentive to Commodity to Asset", supra n. 12, p. 571.

17 See, Drahos, "BITS and BIPS", supra n. 15, p. 793. See also, Henning Gross Ruse-Khan, "Protecting Intellectual Property Rights under BITs, FTAs and TRIPS: Conflicting Regimes or Mutual Coherence?" in Chester Brown and Kate Miles (eds.), Evolution in Investment Treaty Law and Arbitration (CUP, 2011), p. 490.

18 See, Drahos, "BITS and BIPS", supra n. 15, p. 803. See also Ruse-Khan, "Protecting Intellectual Property Rights", supra n. 17, pp. 490-491.

19 For instance, the Reciprocal Investment Promotion and Protection Agreement between Morocco and Nigeria, (3 December 2016), art. 8(8) states that Article 8 dealing with expropriation and compensation "does not apply to the issuance of a compulsory licence granted in relation to intellectual property rights or to the revocation, limitation or creation of an intellectual property right, to the extent that the issuance, revocation, limitation or creation is consistent with the WTO Agreement." It should however be noted that these types of clauses may not necessarily prevent an investor from challenging a measure relating 
Secondly, a number of these investment agreements empower corporations to challenge regulatory measures (implemented by host countries to achieve specific societal goals) before international arbitration tribunals via the Investor-State Dispute Settlement (ISDS) system. ${ }^{20}$ The threat and/or cost of litigation before an investment tribunal pursuant to an investment agreement can influence a country to decide not to implement certain regulatory measures (including measures relating to intellectual property rights) ${ }^{21}$ thus having a chilling effect on the regulatory powers of the country.22

This paper focuses on this second effect and it will assess the extent to which there is still scope for the preservation of the principle of territoriality within the framework of the ISDS system. This assessment is necessary because a number of countries have recently had to defend specific aspects of their national intellectual property laws before investment tribunals. ${ }^{23}$ There have been two decisions on substantive issues in this regard by investment tribunals

to intellectual property on the grounds that the measure is not consistent with the TRIPS Agreement. See generally, Ruse-Khan, "Protecting Intellectual Property Rights", supra n. 17, pp. 504-508. Crucially, Article 1110(7) of NAFTA did not prevent Eli Lilly from challenging Canada's patent law before an investment tribunal.

20 See, Ho, "Sovereignty under Siege", supra n. 15, p. 219; Cynthia Ho, "A Collision Course between TRIPS Flexibilities and Investor-State Proceedings" (2016) 6(3) UC Irvine Law Review 101-175; James Gathii and Cynthia Ho, "Regime Shifting of IP Lawmaking and Enforcement from the WTO to the International Investment Regime" (2017) 18(2) Minnesota Journal of Law, Science \& Technology 427-515.

21 See for instance Sarah Roache, Lawrence Gostin, and Eduardo Fonsalia, "Trade, Investment, and Tobacco: Philip Morris v Uruguay" (2016) 316(20) Journal of the American Medical Association 2085-2086, p. 2086 (noting that, "Canada announced its intention to consider plain packaging [of tobacco products] as early as 1995 but was deterred by a legal opinion by Philip Morris and RJ Reynolds stating the proposed legislation would expropriate the companies' trademarks, requiring hundreds of millions of dollars in compensation under the North American Free Trade Agreement. This concern delayed plain packaging legislation, which Canada is now considering more than 20 years later.").

22 Ho, "Sovereignty under Siege", supra n. 15, p. 233.

23 See, Philip Morris Asia Limited v Australia, PCA Case No. 2012-12 (Award on Jurisdiction and Admissibility) (17 December 2015); Philip Morris Brands Sarl \& Others v Uruguay, ICSID Case No. ARB/10/7, (Award) (8 July 2016) (hereinafter Philip Morris); Eli Lilly v Canada, Case No. UNCT/14/2, (Final Award) (16 March 2017) (hereinafter Eli Lilly). 
and these two cases ${ }^{24}$ will be used to assess the extent of the preservation of the principle of territoriality in the ISDS system. ${ }^{25}$

The first case is the dispute between Philip Morris and Uruguay which concerned the latter's implementation of certain measures to curb the consumption of tobacco products in its country but which Philip Morris construed as an expropriation of its trademarks. ${ }^{26}$ The second case is the dispute between Eli Lilly and Canada which concerned the interpretation of the utility requirement under Canadian patent law. ${ }^{27}$

This paper is structured into three main parts. Part two will examine the impact of the assetization of intellectual property and the ISDS system on the principle of territoriality. Parts three and four will attempt to determine whether there is still scope for the preservation of the principle of territoriality within the ISDS system by examining the decisions of the investment tribunals in the dispute between Philip Morris and Uruguay (in part three) and the dispute between Eli Lilly and Canada (in part four).

\section{The principle of territoriality, the assetization of intellectual property, and the ISDS system}

As noted in the introduction above, assetization of intellectual property is the incorporation of intellectual property rights as investment assets into bilateral investment treaties and investment chapters of free trade agreements. As the

24 Philip Morris, supra n. 23; Eli Lilly, supra n. 23.

25 A third case (Philip Morris Asia Limited $v$ Australia, supra n. 23) was dismissed for lack of jurisdiction and will thus not be examined in this paper.

26 Philip Morris, supra n. 23.

27 Eli Lilly, supra n. 23. 
assetization of intellectual property can enable corporate actors to challenge national intellectual property laws before investment tribunals via the ISDS system, scholars have highlighted the impact that assetization can have on the principle of territoriality in IIPL. ${ }^{28}$ There are a number of ways in which the assetization of intellectual property and the ISDS system can negatively impact the principle of territoriality in IIPL. It should be noted that there are other problems with the ISDS system ${ }^{29}$ and there have been calls from some quarters for the reform of the ISDS system as a whole. ${ }^{30}$ Indeed, in response to criticisms of the current ISDS system, the EU and Canada have recently jointly called for the establishment of a multilateral investment court. ${ }^{31}$ However, this paper only focuses on the aspects of the existing ISDS system that can negatively affect the principle of territoriality in IIPL and two of these are discussed below.

Firstly, as Frankel points out, there is an incongruence between the object and purpose of protecting intellectual property and the object and purpose of

28 See, Dreyfuss and Frankel, "From Incentive to Commodity to Asset", supra n. 12, p.571 (noting that, "once assetization is realized through successive negotiations over IP, investment treaties and investment chapters in free trade agreements become significant for lurking within them are provisions defining IP as assets and a mechanism-investor-state arbitration-that protects these assets from direct or indirect expropriation and guarantees investors fair and equitable treatment.").

29 The ISDS system has been criticised for the lack of consistency in the decisions generated via the system as it has neither binding precedents nor an appellate system. In addition, it has also been criticised for its lack of transparency and its potential to produce decisions that might be inconsistent with other international dispute settlement systems such as the WTO dispute settlement system. See generally, Ho, "Sovereignty under Siege", supra n. 15, pp. 234, 250.

30 Anthea Roberts, "The Shifting Landscape of Investor-State Arbitration: Loyalists, Reformists, Revolutionaries and Undecideds" (EJIL: Talk!, 15 June 2017), available at https://www.ejiltalk.org/the-shifting-landscape-of-investor-state-arbitration-loyalistsreformists-revolutionaries-and-undecideds/ (accessed 3 August 2017).

31 See, Council of the European Union, "Joint Interpretative Instrument on the Comprehensive Economic and Trade Agreement (CETA) between Canada and the European Union and its Member States" 13541/16 (27 October 2016) available at http://data.consilium.europa.eu/doc/document/ST-13541-2016-INIT/en/pdf (accessed 3 August 2017). See also, supra n. 30. 
protecting investment assets. ${ }^{32}$ While intellectual property laws are typically rationalised as instruments for incentivising creativity, investment agreements are aimed at protecting an investor's assets with the expectation of gain or profit. ${ }^{33}$ In addition, while intellectual property rights are typically not absolute rights and the impairment of an intellectual property right either through governmental regulation or third party use might be permissible if it falls within one of the limitations and exceptions to such rights under national laws, the rules for determining what constitutes an expropriation of an investment asset pursuant to an investment agreement may not necessarily overlap with the rules for determining what constitutes a permissible impairment of an intellectual property right. ${ }^{34}$ In other words, a governmental regulation or measure that could be considered a permissible limitation of an intellectual property right under a country's national intellectual property laws could be characterised by an investor as an expropriation of its investment asset pursuant to an investment agreement. This incongruence between the object and purpose of intellectual property law and international investment law might impair the ability of a state to design its national intellectual property laws in a way that enables it to achieve specific societal goals.

Secondly, the ability of investment tribunals to consider the broader public interest when resolving investment disputes has also been called into question. ${ }^{35}$ Frankel contends that "there is scant evidence that many investment

32 See generally, Frankel, "Interpreting the Overlap", supra n. 15, p. 139 (noting that, "At its bluntest, the objects and purposes of international IP ... and the object and purpose of investment agreements are not the same.").

33 Dreyfuss and Frankel, "From Incentive to Commodity to Asset", supra n. 12, p. 572.

34 Ibid.

35 See, Kate Miles, “Reconceptualising International Investment Law: Bringing the Public Interest into Private Business" in Meredith Lewis and Susy Frankel (eds.), International Economic Law and National Autonomy (CUP, 2010), p. 295 (noting that, "Matters of public 
tribunals take into account values which might be described as public goods or interests outside of the litigating parties." ${ }^{36}$ This has serious implications for investment disputes involving intellectual property rights as a country may decide, in the public interest, to introduce specific measures relating to intellectual property rights in a bid to achieve specific societal goals such as protecting public health.

In determining whether there is still scope for the preservation of the principle of territoriality in IIPL within the ISDS system, the two issues identified above will be used as a metric to critically assess the decisions of the tribunals in Philip Morris and Eli Lilly in parts three and four respectively. In other words, how did these tribunals deal with the incongruence between the object and purpose of protecting intellectual property and the object and purpose of protecting investment assets? Did these tribunals give any weight to public interest considerations in their decisions?

\section{Philip Morris v Uruguay}

In order to reduce the consumption of tobacco products in its country, the Uruguay government implemented a number of measures including the "single presentation requirement" (SPR) $)^{37}$ and the "80/80" regulation. ${ }^{38}$ The SPR permits the sale of only one variant of cigarette per brand family i.e. it prohibits the sale of more than one variant of the same brand of cigarette. The $80 / 80$ regulation requires health warnings on $80 \%$ of both sides of cigarette packs, leaving only

interest are inherently involved in investor-state disputes. And yet, the current arbitration model is ill-equipped to address these wider issues.").

36 Frankel, "Interpreting the Overlap", supra n. 15, p. 125.

37 The SPR was implemented via Ordinance 514 of 18 August 2008 of the Uruguayan Ministry of Public Health.

38 The 80/80 regulation was implemented via Presidential Decree No. 287/009 of 15 June 2009. 
$20 \%$ for trademarks, logos and other information. As a result of these measures, Philip Morris sued Uruguay before an investment tribunal pursuant to a bilateral investment treaty between Switzerland and Uruguay. ${ }^{39}$

Philip Morris alleged, among other things, that the two measures constitute an expropriation of its trademarks pursuant to Article 5 of the bilateral investment treaty. ${ }^{40}$ According to Philip Morris, the SPR effectively banned and expropriated seven of its thirteen brand variants and the 80/80 regulation diminished the value of the remaining variants. ${ }^{41}$ Uruguay however contended that the measures were a legitimate exercise of its sovereign police power (i.e. regulatory power $)^{42}$ and the measures were adopted solely for the purpose of protecting public health and not interference with foreign investment. ${ }^{43}$ According to Uruguay, the SPR was adopted to reduce the negative consequences of the promotion of tobacco such as the false marketing by the claimants that certain brand variants are safer than other brand variants. ${ }^{44}$ In addition, Uruguay contended that the 80/80 regulation was adopted to heighten the awareness of consumers about the health risks associated with the consumption of tobacco and to encourage its citizens, including young people, to stop or not start smoking tobacco. ${ }^{45}$

Uruguay also contended that Article 5 of the bilateral investment treaty should be interpreted in accordance with Article 31 of the Vienna Convention on the Law of Treaties which permits a tribunal to consider customary international

\footnotetext{
39 See, Agreement between the Swiss Confederation and the Oriental Republic of Uruguay on the Reciprocal Promotion and Protection of Investments of October 1988 which entered into force in April 1991.

40 Philip Morris, supra n. 23, para. 12.

41 Ibid., paras. 180, 193-194.

42 Ibid., para. 181.

$43 \quad$ Ibid., para. 13.

44 Ibid.

45 Ibid.
} 
law in its interpretation of a treaty. ${ }^{46}$ According to Uruguay, "the police powers doctrine is a fundamental rule of customary international law and as such, it must be applied to interpret Article 5, in accordance with Article 31 of the Vienna Convention on the Law of Treaties." 47 In this regard, Philip Morris contended, among other things, that a state's regulatory measure must be subject to limitations and that, even if the measures were adopted to protect public health, they were still expropriatory because they were unreasonable. ${ }^{48}$

In its decision, the tribunal ruled in favour of Uruguay (although there was a dissenting judgment from one of the arbitrators). ${ }^{49}$ As this was not a case involving the direct expropriation of an investment asset, a key question for the tribunal was whether the measures implemented by Uruguay were an indirect expropriation of the claimants' asset. ${ }^{50}$ According to the tribunal, in order to constitute indirect expropriation, "the government's measures interference with the investor's rights must have a major adverse impact on the Claimants' investments." 51 The tribunal ruled that there was no indirect expropriation and that the measures implemented by Uruguay were a valid exercise of state police powers to protect public health. ${ }^{52}$ As noted in part two above, the two issues

46 See the Vienna Convention on the Law of Treaties of 1969 art. 31(3)(c).

47 Philip Morris, supra n. 23, para. 218.

48 Ibid., para. 198.

49 See, Ibid., para. 2. (Concurring and Dissenting Opinion of Mr Gary Born.) It should be noted that $\mathrm{Mr}$ Born dissented on two issues although he agreed with almost all of the conclusions in the tribunal's award. Importantly, he agreed that the measures implemented by Uruguay were not expropriatory. He however disagreed with the majority with regard to whether there was a denial of justice and a denial of fair and equitable treatment. A thorough discussion of Mr Born's dissenting opinion is however not within the scope of this article.

50 The tribunal noted, "that the legal title to the property representing the Claimants' investment was not affected by the Challenged Measures...Clearly, the Claimants' claim relates to indirect or de facto expropriation, as shown by the reference to this kind of expropriation in their pleadings." Ibid., para. 191.

$51 \quad$ Ibid., para. 192.

$52 \quad$ Ibid., paras. 272-307. 
identified in part two will be used as a metric to determine whether the tribunal's decision indicates that there is any scope for the preservation of the principle of territoriality within the ISDS system.

\subsection{The incongruence resulting from treating trademarks as both an investment asset and as an intellectual property right}

In relation to the first issue i.e. the incongruence between the object and purpose of protecting intellectual property and the object and purpose of protecting investment assets, the tribunal's approach to the interpretation of the nature of the rights conferred on Philip Morris by virtue of its trademarks is highly instructive. In this case, the trademarks (which Philip Morris claimed had been expropriated as a result of the measures implemented by Uruguay) were both simultaneously intellectual property rights and investment assets. ${ }^{53}$ One crucial question that the tribunal had to answer in this regard was whether Philip Morris' trademarks were capable of being expropriated. Philip Morris contended that it had the "right to use" its trademarks in commerce and thus it could be expropriated while Uruguay contended that trademark owners only have a negative "right to exclude" third parties from using their trademarks and not an affirmative "right to use" them. ${ }^{54}$ According to Uruguay, Philip Morris had no rights that could be expropriated since trademarks only confer a negative right to exclude. ${ }^{55}$

In deciding this issue, the tribunal looked beyond the bilateral investment treaty and considered the nature of the right conferred on trademark owners

53 As noted by the tribunal, "It is undisputed that trademarks and goodwill associated with the use of trademarks are protected investments under Article 1(2)(d) of the BIT." Ibid., para.

235. Elsewhere, the tribunal referred to the trademarks as "intellectual property assets." Ibid., para. 273.

54 Ibid., paras. 168, 181.

55 Ibid., para. 181. 
under international trademark law i.e. the Paris Convention and the TRIPS Agreement. This approach suggests that the tribunal was cognisant of the unique status of intellectual property as an investment asset. According to the tribunal, there is nothing in either the Paris Convention or the TRIPS Agreement that confers on trademark owners a positive right to use their trademarks. ${ }^{56}$ The tribunal noted that Article 16 of the TRIPS Agreement only provides for the exclusive right of a trademark owner to prevent third parties from using the same trademark in the course of trade..$^{57}$ The tribunal's analysis did not however stop here. In the tribunal's view, rather than frame the issue as one between a right to use and a right to exclude third parties, it is better to frame the issue as a choice between an absolute versus exclusive right to use. ${ }^{58}$ According to the tribunal:

Ownership of a trademark does, in certain circumstances, grant a right to use it. It is a right of use that exists vis-à-vis other persons, an exclusive right, but a relative one. It is not an absolute right to use that can be asserted against the State qua regulator..$^{59}$

Thus, while recognising that there is no provision under international trademark law that expressly confers a right to use a trademark on the owner, the tribunal adopted the view that the ownership of a trademark could in certain cases confer a right to use it. It should be noted that there is a divergence of opinion on this issue amongst scholars. Some scholars hold to the view, canvassed by Uruguay in this case, that trademark owners only have a negative right to exclude third parties from using their trademarks. ${ }^{60}$ Other scholars such

Ibid., paras. 260-262.

57 Ibid., para. 262.

58 Ibid., para. 267.

59 Ibid.

60 See generally, Andrew Mitchell, "Australia's Move to the Plain Packaging of Cigarettes and its WTO Compatibility" (2010) 5(2) Asian Journal of WTO Law and International Health Law and 
as Frankel and Gervais however hold a contrary view and contend that "there is a leap in logic from saying that because Article 16 frames certain rights as exclusive rights against infringement (negative rights), therefore trademark owners have no rights to use (positive rights)." ${ }^{61}$ They further contend that trademarks are not registered solely to obtain a government certificate but people "register them because they are using the trademark in commerce (or intend to)." 62 They equally point out that, embedded in Article 17 of the TRIPS Agreement, is a recognition of the legitimate interests of trademark owners. ${ }^{63}$ In other words, Article 17 seems to go beyond a mere right to exclude as it provides that the "legitimate interests of the owner of the trademark" must be taken into account when members provide limited exceptions to trademark rights. Frankel and Gervais refer to a decision of a WTO dispute settlement panel in European Communities - Protection of Trademarks and Geographical Indications for Agricultural Products and Foodstuffs where the panel stated that:

Every trademark owner has a legitimate interest in preserving the distinctiveness, or capacity to distinguish, of its trademark so that it can perform that function. This includes its interest in using its own trademark

Policy 405-426, pp. 415-416. Mitchell also relies on the ruling of the WTO Panel in European Communities - Protection of Trademarks and Geographical Indications for Agricultural Products and Foodstuffs (15 March 2005) WT/DS174/R, para. 7.210, where the Panel stated that the TRIPS Agreement "does not generally provide for the grant of positive rights to exploit or use certain subject matter, but rather provides for the grant of negative rights to prevent certain acts." Other scholars who hold this view include: Henning Grosse Ruse-Khan, "Assessing the Need for a General Public Interest Exception in the TRIPS Agreement" in Annette Kur (ed.), Intellectual Property Rights in a Fair World Trade System: Proposals for Reform of TRIPS (Edward Elgar, 2011), p. 197; Tania Voon and Andrew Mitchell, "Implications of WTO Law for Plain Packaging of Tobacco Products" in Tania Voon et al. (eds.), Public Health and Plain Packaging of Cigarettes: Legal Issues (Edward Elgar, 2012), pp. 115-119.

61 See, Susy Frankel and Daniel Gervais, "Plain Packaging and the Interpretation of the TRIPS Agreement" (2013) 46(5) Vanderbilt Journal of Transnational Law 1149-1214, p. 1188.

62 Ibid., p. 1212.

63 Ibid. 
in connection with the relevant goods and services of its own and authorized undertakings. ${ }^{64}$

It will thus appear that even though there is no express provision in the TRIPS Agreement conferring a right to use on trademark owners, this does not mean that trademark owners do not have a legitimate interest in using their trademarks in commerce. The tribunal however did not deem it necessary to consider whether trademark owners have a legitimate interest in using their trademarks. ${ }^{65}$ Nevertheless, the tribunal concluded its analysis on this question by ruling that:

...under Uruguayan law or international conventions to which Uruguay is a party the trademark holder does not enjoy an absolute right of use, free of regulation, but only an exclusive right to exclude third parties from the market so that only the trademark holder has the possibility to use the trademark in commerce, subject to the State's regulatory power. ${ }^{66}$

Thus, the crucial point to note here is that trademarks are not absolute rights and they are subject to the state's regulatory power. In other words, despite the dual nature of the trademarks involved in this dispute (i.e. as both intellectual property and investment assets), the tribunal still recognised the unique status of intellectual property rights in the context of investment agreements. The approach of the tribunal in this regard is in line with the object and purpose of the TRIPS Agreement which provides in Article 8 that, in formulating or amending their national intellectual property laws, countries can adopt measures

\footnotetext{
64 WTO, European Communities - Protection of Trademarks and Geographical Indications for Agricultural Products and Foodstuffs (15 March 2005) WT/DS174/R, para. 7.664.

65 See, Philip Morris, supra n. 23, para. 271, footnote 346.

66 Ibid., para. 271.
} 
necessary to protect public health and nutrition. As the tribunal pointed out in its analysis, "if a food additive is, subsequent to the grant of a trademark, shown to cause cancer, it must be possible for the government to legislate so as to prevent or control its sale notwithstanding the trademark." 67 Consequently, simply because a trademark is an investment asset, it does not mean that it therefore becomes immune from a state's regulatory power. The approach of the tribunal in this regard thus accords with, and preserves, the principle of territoriality.

\subsection{The public interest}

In relation to the second issue i.e. the ability of investment tribunals to consider the broader public interest when resolving investment disputes, the approach of the tribunal in this regard appears to be contrary to the view that "there is scant evidence that many investment tribunals take into account values which might be described as public goods or interests outside of the litigating parties." 68 The approach of the tribunal with regard to considering the broader public interest can be discerned in its analysis of the question concerning whether the measures introduced by Uruguay expropriated Philip Morris' investment.

According to the tribunal, the $80 / 80$ regulation did not constitute an indirect expropriation and it held that a "limitation to $20 \%$ of the space available to such purpose could not have a substantial effect on the Claimants' business since it consisted only in a limitation imposed by the law on the modalities of use of the relevant trademarks." 69 The tribunal also stated that the SPR did not substantially deprive the claimants of the value, use or enjoyment of their

\footnotetext{
$67 \quad$ Ibid., para. 269.

68 Frankel, "Interpreting the Overlap", supra n. 15, p. 125.

69 Philip Morris, supra n. 23, para. 276.
} 
investments. ${ }^{70}$ The tribunal took note of the fact that Philip Morris admitted this much when they mentioned that "while Abal [one of the claimant companies owned by Philip Morris] has grown more profitable since 2011, Abal would have been even more profitable if Respondent has not adopted the challenged measures." ${ }^{71}$ The tribunal took the view that:

...in respect of a claim based on indirect expropriation, as long as sufficient value remains after the Challenged Measures are implemented, there is no expropriation. As confirmed by investment treaty decisions, a partial loss of the profits that the investment would have yielded absent the measure does not confer an expropriatory character on the measure. ${ }^{72}$

Apart from holding that the measures implemented by Uruguay did not constitute an expropriation of the trademarks, the tribunal further held that the adoption of the measures was a valid exercise of Uruguay's police powers. ${ }^{73}$ The tribunal's analysis with regard to the police powers doctrine offers an interesting insight into its approach towards considering the public interest. The tribunal took the view that Article 5 of the bilateral investment treatment (which deals with expropriation) must be interpreted in accordance with Article 31(3)(c) of the Vienna Convention on the Law of Treaties which permits reference to customary international law. Relying on this approach, the tribunal noted that "protecting public health has since long been recognized as an essential manifestation of the State's police power."74

\footnotetext{
70 Ibid., para. 284.

1 Ibid.

72 Ibid., para. 286.

Ibid., para. 287.

74 Ibid., para. 291.
} 
The tribunal traced the historical development of the police powers doctrine in international investment law and it noted that, while it was not initially recognised by tribunals, "a consistent trend in favour of differentiating the exercise of police powers from indirect expropriation emerged after 2000."75 As noted by Pellet, the police powers doctrine or the state's right to regulate "accepts that a non-discriminatory taking of property without compensation can be lawful, if decided for a reason of public interest" and "its purpose is to preserve the right of the State to regulate in the public interest."76

Instructively, the tribunal "stressed that the SPR and the 80/80 Regulation have been adopted in fulfilment of Uruguay's national and international legal obligations for the protection of public health."77 The tribunal took note of the fact that Uruguay had obligations both under its national constitution and the WHO's Framework Convention on Tobacco Control (FCTC) to protect its citizens from the harmful effects of tobacco. ${ }^{78}$ Importantly, the tribunal even incorporated a human rights perspective into its decision by noting that the "FCTC is one of the international conventions to which Uruguay is a party guaranteeing the human rights to health; it is of particular relevance in the present case, being

75 Ibid., para. 295. In this regard the tribunal referred to the following cases: Tecmed $v$ Mexico (29 May 2003) ARB (AF)/00/2 (Award); Methanex v United States (3 August 2005) (Final Award); Saluka v Czech Republic (17 March 2006) (Partial Award); Chemtura v Canada (2 August 2010) Award.

76 Alain Pellet, "Police Powers or the State's Right to Regulate: Chemtura v. Canada" in Meg Kinnear et al. (eds.), Building International Investment Law - The First 50 Years of ICSID (Kluwer Law International, 2015), p. 449. See also, Aikaterini Titi, The Right to Regulate in International Investment Law, (Nomos, 2014); Kate Mitchell, "Philip Morris v Uruguay: An Affirmation of 'Police Powers' and 'Regulatory Power in the Public Interest' in International Investment Law" (EJIL: Talk!, 28 July 2016), available at https://www.ejiltalk.org/philipmorris-v-uruguay-an-affirmation-of-police-powers-and-regulatory-power-in-the-publicinterest-in-international-investment-law/ (accessed 3 August 2017).

77 Philip Morris, supra n. 23, para. 302.

78 Ibid., paras. 302-304. 
specifically concerned to regulate tobacco control." 79 The tribunal took the view that the SPR and the $80 / 80$ regulation satisfied the conditions that must be fulfilled for a state's exercise of its regulatory powers not to constitute indirect expropriation i.e. it was taken bona fide to protect the public welfare (specifically public health in this case), it was non-discriminatory, and it was proportionate. ${ }^{80}$

The tribunal's approach to the question of whether the measures implemented by Uruguay constitute an expropriation of Philip Morris' investments and its invocation of the police powers doctrine demonstrates that there is still some scope and hope for the preservation of the principle of territoriality within the ISDS system. This is important because even under the TRIPS Agreement, pursuant to Articles 8 and 20, countries are permitted to introduce measures to regulate the use of trademarks in order to protect the public health. ${ }^{81}$

\section{Eli Lilly v Canada}

This case centres around the invalidation between 2010 and 2011, of two pharmaceutical patents (on two drugs, Strattera and Zyprexa) belonging to Eli Lilly by Canadian courts based on a failure to satisfy Canada's utility requirement. ${ }^{82}$ Eli Lilly alleged that this was an expropriation pursuant to the

79 Ibid., para. 304.

80 Ibid., paras. 305-306.

81 Supra n. 61. There is currently a dispute at the WTO concerning Australia's tobacco plain packaging laws and a decision is expected shortly. See, Australia - Certain Measures Concerning Trademarks, Geographical Indications and Other Plain Packaging Requirements Applicable to Tobacco Products and Packaging WT/DS567. Unconfirmed early reports suggest that the WTO Panel upheld Australia's plain packaging laws. See, Tom Miles and Martinne Geller, "Australia Wins Landmark WTO Tobacco Packaging Case - Bloomberg" (Reuters, 4 May 2017), available at http://www.reuters.com/article/us-wto-tobacco-australiaidUSKBN1801S9 (accessed 3 August 2017).

82 Eli Lilly, supra n. 23, para. 5. 
North American Free Trade Agreement (NAFTA). In order to fully understand Eli Lilly's complaint in this regard, it is necessary to provide some background on Canada's utility requirement.

According to section 2 of the Canadian Patent Act, an invention "means any new and useful art, process, machine, manufacture or composition of matter, or any new and useful improvement in any art, process, machine, manufacture or composition of matter." Section 27(3)(a) of the Act further provides that the specification of an invention must "correctly and fully describe the invention and its operation or use as contemplated by the inventor." Thus, similar to the situation in most countries, under Canadian patent law, an invention must satisfy the utility requirement. What is however unique about the Canadian utility requirement is the yardstick that Canadian courts developed over time to determine what satisfies the utility requirement. The Canadian Federal Courts developed the "promise of the patent" or "the promise doctrine" according to which if a patent application (construed as a whole) promises a specific utility, the invention would not satisfy the utility requirement unless that promise is fulfilled. As stated by the Canadian Federal Court of Appeal in Eli Lilly $v$ Novopharm Ltd,

Where the specification does not promise a specific result, no particular level of utility is required; a "mere scintilla" of utility will suffice. However, where the specification sets out an explicit "promise", utility will be measured against that promise...The question is whether the invention does what the patent promises it will do. ${ }^{83}$

83 Eli Lilly v Novopharm Ltd., 2010 FCA 197, para. 76. 
As developed by the Canadian courts, the promise of a patent is determined by examining the patent as a whole (including the claims and specification). ${ }^{84}$ After identifying the promises, the doctrine requires that these promises be fulfilled either by demonstration or sound prediction and it equates the fulfilment of these promises with the utility requirement in section 2 of the Patent Act. ${ }^{55}$ According to the doctrine, if any of the promises are not fulfilled, then the invention would be deemed to have failed to meet the utility requirement. ${ }^{86}$

However, in June 2017, just a few months after the tribunal's decision in the dispute between Eli Lilly and Canada, the Canadian Supreme Court held that the promise doctrine is unsound and that its interpretation of the utility requirement is incongruent with the words and scheme of the Patent Act. ${ }^{87}$ Importantly, the Supreme Court held that the doctrine conflates the utility requirement (in section 2) with the disclosure requirement (in section 27(3)) of the Patent Act. ${ }^{88}$

The merits or otherwise of the Canadian Supreme Court's decision is however not the focus of this paper. It suffices to state here that, under the principle of territoriality in IIPL, a country is free to strengthen or weaken its patentability requirements and thus Canada (either through its parliament or courts) is free to change its mind about the promise doctrine. This paper is instead concerned with the question of whether the application of the promise doctrine prior to June 2017, resulting in the invalidation of a number of patents including

\footnotetext{
84 Ibid., para. 80.

85 See, AstraZeneca v Apotex, 2017 SCC 36, para. 31.

86 Ibid.

87 Ibid., para. 36.

88 Ibid., paras. 43-44.
} 
Eli Lilly's pharmaceutical patents, constitutes an expropriation of Eli Lilly's patent.

The crux of Eli Lilly's complaint was that Canadian courts developed the promise doctrine in the mid-2000s after it had been granted its patents and it contended that this was a radical development. ${ }^{89}$ Importantly, it also contended that the doctrine is inconsistent with Canada's obligation under NAFTA and that the retroactive application of the doctrine to its patent amounted to, inter alia, an unlawful expropriation under Article 1110 of NAFTA. ${ }^{90}$ In response, Canada contended, among other things, that a national court decision could only breach NAFTA if there had been a denial of justice, that there had been no radical change in the way Canadian courts interpreted the utility requirement, and that the invalidation of Eli Lilly's patent did not amount to a breach of its obligation under NAFTA or any other international obligation. ${ }^{91}$

The tribunal ruled in favour of Canada and it held that Eli Lilly had failed to demonstrate that there had been a radical change in the way Canadian courts construed the utility requirement. ${ }^{92}$ The tribunal equally ruled that the invalidation of Eli Lilly's patents was not a breach of Canada's obligations under NAFTA and was therefore not an expropriation. ${ }^{93}$ However, the ruling of the tribunal appears to suggest that an investor can challenge the decisions of a country's courts before an investment tribunal even where there has been no denial of justice. ${ }^{94}$ A critical discussion of the tribunal's ruling in relation to denial

89 Eli Lilly, supra n. 23, para. 5.

90 Ibid.

91 Ibid., para. 6.

92 Ibid., para. 387.

93 Ibid., para. 469.

94 While stressing that an investment tribunal is not an appellate tier in relation to national court decisions, the tribunal stated that, "it is evident that there are distinctions to be made between conduct that may amount to a denial (or gross denial) of justice and other conduct that may also be sufficiently egregious and shocking, such as manifest arbitrariness or 
of justice is however beyond the scope of this paper as the focus here is on the tribunal's ruling on whether the invalidation of Eli Lilly's patents amounted to an expropriation. ${ }^{95}$ As was done in part three above, the two issues identified in part two will be used as a metric to determine whether the tribunal's decision indicates that there is any scope for the preservation of the principle of territoriality within the ISDS system.

\subsection{The incongruence resulting from treating patents as both an investment asset and as an intellectual property right}

In relation to the incongruence between the object and purpose of protecting inventions via the patent system and the object and purpose of protecting inventions as investment assets, the tribunal's decision on three questions is quite instructive. The three questions relate to: (1) whether there had been a radical change in the way Canadian courts applied the utility doctrine; (2) whether Eli Lilly had a legitimate expectation that its patents would not be invalidated; and, (3) whether NAFTA or international patent law requires countries to have a uniform approach to defining the utility requirement.

With regard to the first question, Eli Lilly alleged that the promise doctrine constitutes a radical change from the traditional utility standard which Canada had been applying prior to the adoption of the doctrine by Canadian courts in the mid-2000s and which is still being applied by other parties to NAFTA i.e.

blatant unfairness...As a matter of principle, therefore, having regard to the content of the customary international law minimum standard of treatment, the Tribunal is unwilling to shut the door to the possibility that judicial conduct characterized other than as a denial of justice may engage a respondent's obligations under NAFTA Article 1105..." See, ibid., para. 223.

95 For a critique of the tribunal's ruling in relation to denial of justice see, Rob Howse, "Eli Lilly v Canada: A Pyrrhic Victory against Big Pharma" (International Economic Law and Policy Blog, 26 March 2017), available at http://worldtradelaw.typepad.com/ielpblog/2017/03/elililly-v-canada-a-pyrrhic-victory-against-big-pharma-.html (accessed 3 August 2017). 
USA and Mexico. ${ }^{96}$ In response, Canada contended that as the term "useful" is not defined in the Patent Act, its meaning has evolved through judicial jurisprudence and there was therefore no radical change in the law.${ }^{97}$ In its ruling, the tribunal acknowledged that the process of the development of the doctrine shows that there had been some change but it ruled that the "change is more incremental and evolutionary than dramatic." 98 Essentially, the tribunal ruled that Eli Lilly "has not demonstrated a fundamental or dramatic change in Canadian patent law." 99

The tribunal's approach in this regard however raises the question of what would constitute a radical change in a country's patent law that could be construed as an expropriation. The only reason that Eli Lilly failed in this regard was because it could not establish that there had been a radical change in Canadian patent law. But what if another company in a future case is able to establish that there had been a radical change? The tribunal's decision does not offer clear guidance on what kind of change can amount to a radical change and this can have a significant impact on a country's regulatory power (and by implication, the principle of territoriality). There is nothing in the TRIPS Agreement or NAFTA that prevents a country's court from adopting an interpretive approach that strengthens its patentability requirements in order to address legitimate concerns within the country such as the need to prevent speculative patenting. These developments, while they might appear to be "radical" changes to an investor, are well within the regulatory powers of a state under international patent law. The tribunal's approach in this regard therefore appears to leave the door open for investors to challenge national court decisions

\footnotetext{
96 Eli Lilly, supra n. 23, para. 227.

97 Ibid., para. 270.

98 Ibid., para. 350.

$99 \quad$ Ibid., para. 387.
} 
that they might view as constituting "radical" changes to previously existing standards. As Howse notes:

On those exceptional but usually very important occasions when high courts reconsider well-established judicial doctrines in the face of social, economic, environmental or other forms of rapid change we experience in the world today they must now beware that any basic or fundamental reorientation of their jurisprudence could force that state's government to pay out millions or even billions to foreign corporations in the guise of an "expropriation" having occurred. ${ }^{100}$

It is suggested here that a preferable approach would have been for the tribunal to recognise a country's regulatory power to change (either through its parliament or its courts) its patent laws to suit its needs and interests. As long as this change is in accordance with the provisions of the Paris Convention and the TRIPS Agreement, a country should not have to defend any change in its patent law before an investment tribunal. More importantly, the question should not have been whether or not there had been a radical change in Canada's patent law but whether the alleged change in Canada's utility requirement is in line with international patent law as codified in the Paris Convention and the TRIPS Agreement. It is instructive to note that neither the Paris Convention nor the TRIPS Agreement (or even NAFTA for that matter) define the utility requirement thus giving countries the discretion to define what constitutes utility under their national patent laws. In other words, Canada is well within its rights to adopt a unique approach in its definition of what constitutes a useful invention under international patent law.

100 Supra n. 95. 
In relation to the second question i.e. whether Eli Lilly had a legitimate expectation that its patents would not be invalidated, Eli Lilly contended that it "reasonably relied upon the traditional utility requirement in Canadian patent law throughout the process of developing Zyprexa and Strattera, and continued to do so as it brought the drugs to market."101 In addition, Eli Lilly argued that the grant of the patents constituted a commitment by Canada that Eli Lilly "would have exclusive rights to make, use and sell its invention until the expiry of the patents." 102 Eli Lilly drew a distinction between the "normal risk of invalidation" and the "unacceptable risk that a patent will be tested against a new patentability requirement that could not have been foreseen at the time the patent was granted."103

In response, Canada contended, inter alia, that the grant of a patent cannot be relied upon as a basis for legitimate expectation because patents are merely presumptively valid subject to challenge and final determination by courts. ${ }^{104}$ Canada also argued that, when Eli Lilly applied for its patents, it should have known that, if its patent did not meet the patentability requirements, they could be invalidated and "that the legal meaning of patentability requirements is constantly being clarified and elaborated through court decisions." ${ }^{105}$ In Canada's view, the only legitimate expectation that Eli Lilly could have was to receive a fair hearing when its patents were challenged and it did receive one. ${ }^{106}$ Importantly, Canada rejected Eli Lilly's contention that there was a violation of

\footnotetext{
101 Eli Lilly, supra n. 23, para. 263.

102 Ibid., para. 264.

103 Ibid., para. 266.

104 Ibid., para. 306.

105 Ibid., para. 303.

106 Ibid., para. 305.
} 
its legitimate expectations because of a dramatic change in the law and it stated that,

[e]ven if such a change had occurred, it is trite to say that the common law evolves over time. Any sophisticated investor expects developments in the law, particularly in the area of patent law. It simply cannot be that every time a court overrules a precedent, it violates customary international law. ${ }^{107}$

In its decision, the tribunal noted that Eli Lilly's allegation of a violation of its legitimate expectation depended on establishing that there was a radical change in Canada's utility requirement and, since Eli Lilly could not establish that there was a radical change, its allegation in this regard must be dismissed. ${ }^{108}$ Nevertheless, the tribunal still noted that every patentee knows that their patents can be challenged before national courts on the grounds of a failure to satisfy patentability requirements. ${ }^{109}$ According to the tribunal, Eli Lilly's expectation that its patents would not be invalidated for failure to meet the utility requirement "cannot amount to a legitimate expectation."110

The tribunal's decision in this regard accords with the principle of territoriality. Patents, like other forms of intellectual property rights, can always be challenged before national courts and they can be invalidated for failure to satisfy the statutory requirements. International intellectual property law also gives countries the freedom to define patentability requirements and the grounds on which a patent can be invalidated in their national law. Simply because a patent is also an investment asset should not change the fact that the patent is

\footnotetext{
107 Ibid., para. 306.

108 Ibid., para. 380.

109 Ibid., para. 382.

110 Ibid., paras. 383-384.
} 
just presumptively valid. Thus, an investor cannot legitimately expect that its patents will not be invalidated by the courts.

In relation to the third question i.e. whether NAFTA or international patent law requires countries to have a uniform approach to defining the utility requirement, Eli Lilly contended (in support of its allegation that there had been a radical change in Canada's utility requirement) that Canada's promise doctrine was an outlier when compared with the position in the other parties to NAFTA (i.e. USA and Mexico). ${ }^{111}$ Eli Lilly also alleged that Canada's "promise utility doctrine constitutes a new and radical departure from the traditional patent law concept of utility as reflected in the laws of many countries." 112 In response, Canada contended, inter alia, that "any differences in patent law regimes across jurisdictions [are] irrelevant" because "international patent law is not harmonized by NAFTA or otherwise." Furthermore, Canada stressed that no other country (apart from the United States Trade Representative in its 2014 and 2015 Special 301 Reports) or international organisation had complained about its utility requirement. ${ }^{113}$

In its decision on this question, the tribunal noted that the only complaint against Canada's utility requirement was made by the United States Trade Representative's (USTR) Special 301 reports of 2014 and 2015 and it stated that this "silence [from other countries, including Mexico] speaks louder than the single, brief criticism contained in the USTR's Special 301 Report." ${ }^{114}$ Essentially, the tribunal ruled that Eli Lilly's comparison of Canada's utility requirement

\footnotetext{
111 Ibid., para. 258.

112 Ibid., para. 260.

113 Ibid., para. 298.

114 Ibid., para. 378.
} 
with that of other countries does not alter its findings that there had been no radical change in Canada's utility requirement. ${ }^{115}$

The tribunal's decision in this regard accords with, and preserves, the principle of territoriality. Since there is no treaty that codifies the meaning of the utility requirement, countries are free to define this requirement as they so wish in their national patent laws. There is nothing in the Paris Convention, TRIPS Agreement, or NAFTA, that harmonises the patentability requirements. Crucially, the TRIPS Agreement and NAFTA only contain minimum (but not harmonised) standards in relation to patentability requirements. ${ }^{116}$ There is therefore nothing surprising about the fact that different countries might have different definitions with regard to patentability requirements.

\subsection{The public interest}

One of the contentions of Eli Lilly was that the promise doctrine is arbitrary because it, inter alia, served no legitimate public purpose. ${ }^{117}$ In Eli Lilly's view, Canada had "failed to identify any credible policy objective advanced by the promise utility doctrine."118 In response, Canada rejected the view that the doctrine is arbitrary and it contended, among other things, that some of the elements of the doctrine such as requiring patent applicants to demonstrate or soundly predict the utility of an invention at the time of filing is aimed at preventing the granting of patents on the basis of bare speculation. ${ }^{119}$ Canada equally contended that requiring patent applicants to disclose the basis of their

\footnotetext{
115 Ibid., para. 379.

116 The TRIPS Agreement and NAFTA simply state that an invention must be useful/capable of industrial application without defining what this means. See, TRIPS Agreement, art. 27 and NAFTA, art. 1709.

117 Eli Lilly, supra n. 23, para. 390.

118 Ibid., para. 396.

119 Ibid., para. 406.
} 
sound predictions is not arbitrary but is rather "an essential part of the patent bargain." ${ }^{120}$ Essentially, Canada contended that all the elements of the promise doctrine "serve important policy objectives." 121

In its ruling in this regard, the tribunal noted that it was necessary to consider Eli Lilly's allegation in this regard (despite finding that there was no radical change in Canada's utility requirement) because an arbitrary or discriminatory measure can violate NAFTA even in the absence of a radical change in the law. ${ }^{122}$ However, it held that the decisions of the Canadian courts with regard to the promise doctrine were neither arbitrary nor expropriatory. ${ }^{123}$ Importantly, the tribunal found that Canada had "asserted a legitimate public policy justification for the promise doctrine."124 In particular, the tribunal noted that Canada had explained that holding patent applicants to the promises disclosed in their patents discourages overstatements in patent disclosure and is part of the patent bargain. ${ }^{125}$ Importantly, in relation to one of the elements of the promise doctrine which prevents patent applicants from submitting evidence to prove utility after the filing of an application, the tribunal stated that, while this might make it difficult for an applicant to identify when all the patentability requirements can be met and when to file its patent application, "this is the consequence of a rational policy approach in Canada, not an indication of arbitrariness in the law" and that it is not the tribunal's role to question the policy choices of Canada. ${ }^{126}$

\footnotetext{
120 Ibid., para. 407.

121 Ibid., para. 408.

122 Ibid., para. 416.

123 Ibid., para. 418.

124 Ibid., para. 423.

125 Ibid.

126 Ibid., para. 426.
} 
The tribunal's deference to Canada's policy choices in this regard is commendable. The approach of the tribunal in relation to this issue is also in accordance with the principle of territoriality in IIPL. It is important for investment tribunals to recognise and respect the policy choices that countries make (either through their parliament or courts) with regard to their patent laws specifically or intellectual property laws generally. International intellectual property law, especially the TRIPS Agreement, permits countries to adopt policies that are in the public interest and which are aimed at achieving specific societal goals such as preventing speculative patenting, prohibiting the patenting of trivial modifications of previously known medicines, or facilitating access to affordable generic drugs. ${ }^{127}$

\section{Conclusion}

This paper does not intend to make any radical suggestions for the reform of the ISDS system ${ }^{128}$ and neither does it pretend to have exhaustively examined all the potential ways in which the international investment law regime can impact the principle of territoriality in IIPL. For instance, investors typically rely on other concepts such as the denial of justice and the lack of fair and equitable treatment in support of their claims before investment tribunals. While these other concepts

127 See generally, TRIPS Agreement, arts. 1, 7, and 8 and WTO, Doha Declaration on TRIPS and Public Health (20 November 2001) WT/MIN(01)/DEC/2.

${ }^{128}$ For some criticisms of and suggestions on how to reform the ISDS system, see generally, Sachet Singh and Soorai Sharma, "Investor-State Dispute Settlement Mechanism: The Quest for a Workable Roadmap" (2013) 29(76) Merkourios - Utrecht Journal of International and European Law 88-101; Jan Kleinheisterkamp and Lauge Poulsen, "Investment Protection in TTIP: Three Feasible Proposals" in Marc Bugenberg et al. (eds.), European Yearbook of International Economic Law 2016 (Springer, 2016) pp. 527-541; Lise Johnson and Lisa Sachs, "The Outsized Costs of Investor-State Dispute Settlement" (2016) 16(1) Academy of International Business Insights 10-13. For a response to criticisms of the ISDS system see, Gloria Alvarez et al., "A Response to the Criticism against ISDS by EFILA" (2016) 33(1) Journal of International Arbitration 1-36. 
have not been thoroughly examined in this paper, this does not imply that they cannot have an impact on the principle of territoriality in IIPL. Furthermore, the cost of defending an investment dispute ${ }^{129}$ and the possibility of being ordered to pay a huge amount of money as compensation ${ }^{130}$ to an investor may deter states from implementing measures relating to intellectual property that can subsequently be challenged before an investment tribunal.

This paper instead focuses on whether there is still some scope for the preservation of the principle of territoriality in the ISDS system by examining how investment tribunals have construed what constitutes an expropriation in two recent cases involving "intellectual property assets". While one should be wary of jumping to conclusions based on the outcome of only two cases, these two cases provides some basis for cautious optimism. A critical examination of these two cases suggests that there is still some scope for the preservation of the principle of territoriality in the ISDS system although a lot depends on how a tribunal approaches the question of what amounts to an expropriation. A critical reading of the two cases discussed in this paper suggests that, if tribunals adopt a broad interpretive approach when construing bilateral investment treaties and investment chapters of free trade agreements in disputes involving "intellectual property assets," they can arrive at decisions that preserve the regulatory powers

129 It should be noted that even though Uruguay won and Philip Morris lost, the tribunal only ordered Philip Morris to pay $\$ 7$ million out of the $\$ 10.3$ million that Uruguay claimed it spent on legal costs. In other words, Uruguay had to bear the cost of the remaining $\$ 3.3$ million. See, Philip Morris, supra n. 23, paras. 582-588.

130 For instance, in its claim against Canada, Eli Lilly demanded for the sum of CDN \$500 million as compensation for the losses it claimed to have suffered as a result of Canada's breach of its obligation under NAFTA. See, Eli Lilly (Notice of Arbitration) (12 September 2013), para. 85. See also, Dreyfuss and Frankel, "From Incentive to Commodity to Asset", supra n. 12 , pp. 573-574. 
of states whilst simultaneously preventing corporate actors from abusing and misusing a system designed to protect investors with genuine grievances.

There is no rule of international law that prevents investment tribunals from adopting a broad interpretive approach when construing investment treaties. A broad interpretive approach will permit investment tribunals to incorporate relevant principles from other areas of international law such as international intellectual property law and international human rights law when deciding disputes between states and corporate actors. Furthermore, with the current legitimacy crisis confronting the ISDS system, the adoption of a broad interpretive approach that incorporates broader public interests and which respects the legitimate policy choices made by states will go a long way towards enhancing the credibility of investment tribunals as reliable and responsible dispute settlement forums. 